\title{
ANNOUNCEMENTS
}

\section{IN MEMORIAM: EDWIN HAVILAND MILLER}

Just before Christmas 2000 I received a card from Rosalind Miller, Edwin Haviland Miller's wife. I had sent her and Ed our annual holiday greetings, not knowing exactly Ed's medical condition. I knew that he was suffering from Alzheimer's Disease, but I hadn't heard anything more until Roz's card arrived. "Sorry to report," she wrote in a shaky hand, "last couple of years not good. I'm doing fine after cancer episode, except for writing, but Ed in nursing home, Alzheimer's. But we had 55 wonderful years! Enjoy yours!" Edwin Haviland Miller died on September 17, 2001, at the age of eighty-three.

I first corresponded with Ed Miller in the early 1970s. I was editing the Civil War letters of George Washington Whitman and had asked about living relatives who might have relevant documents or even letters. He mentioned the existence of a Walt Whitman Swertfager either in upstate New York or out on the tip of Long Island, where Whitman's sister Mary had lived. Apparently, Swertfager knew nothing about Whitman; furthermore, Ed advised me against contacting him in case he or another relative smelled money in my book (which there wasn't!). I later met Miller at MLA meetings, mainly through Gay Wilson Allen, whom I always viewed as Ed's Whitman mentor, though I'm not sure Ed would agree with that description of the relationship. They were great friends and colleagues at New York University, where Ed taught after fourteen years in the English Department at Simmons College. Ed was around fifteen years younger than Gay, who died in 1995 at the age of ninety-three.

In the late 1970s, while I was living in Concord, Massachusetts, one summer and conducting research for my book on Emerson, Whitman, and the American Muse, my wife Cathy and I drove up to Rockport to have dinner with the Millers. Before dining we swam in one of the nearby stone quarries, which were black and deep. Ed and Roz had rented the same summer home in Rockport for many years. The dinner was exquisite, and Cathy has been making Roz's spinach and zucchini gazpacho ever since. I also dined once with Roger Asselineau at the Miller home in Riverdale, New York. After walking up what seemed like half of Manhattan to the Metropolitan Museum, Roger and I took the subway to the end of the line in Riverdale, where Ed was waiting for us. It was another great dinner, but I observed that Ed, then about eighty, had begun to show some signs of lifetime wear. In his study, I noted the Hawthorne volumes, which were soiled by so many consultations during the writing of his biography of Hawthorne, Salem Is My Dwelling Place (1991). Among his many Whitman publications was the masterful "mosaic of interpretations" of "Song of Myself" (1989). For critical and psychological insights at their best, there is his Walt Whitman's Poetry: A Psychological fourney (1968). And he edited several influential Whitman volumes, including $A$ Century of Whitman Criticism (1969), The Artistic Legacy of Walt Whitman (1970, a tribute to Gay Allen on his retirement from New York University), and the Selected Letters of Walt Whitman 
(1990).

But the grandest scholarly accomplishment for this Harvard Ph.D. (his dissertation was in English Renaissance studies) is the six-volume Walt Whitman: The Correspondence (1961-1977), so thoroughly and accurately annotated as to constitute a living biography of the poet. As a Whitman scholar for many years and the author of the latest biography, I can attest to the absolute reliability of this monumental work. Ed continued to work on collecting stray Whitman letters, adding a supplement to his six volumes with a special double issue of $W W Q R$ in 1991 that gathered nearly fifty newly discovered letters. Ed's work continues to be built upon and added to: we will keep finding more letters (as Ted Genoways's collection in this issue of WWQR amply demonstrates), but Ed's edition remains the foundation and main structure.

Edwin Haviland Miller recharted the landscape for Whitman scholars and along the way wrote on other major figures in American (as well as English) literature, including a controversial biography of Melville (1975). At the time he was stricken with Alzheimer's he was hard at work on a biography of Frank Norris. He was an eminent scholar, an excellent writer, and a good friend.

-JEROME LOVING

\section{THE RETURN OF THE MICKLE STREET REVIEW}

Camden was originally an accident, but I shall never be sorry I was left over in Camden. It has brought me blessed returns. - Walt Whitman

Named for the street in Camden, New Jersey, on which Whitman lived for the last eight years of his life, The Mickle Street Review, a peer-reviewed electronic journal published by the English department at Rutgers University-Camden in cooperation with the Walt Whitman Program in American Studies, seeks to re-imagine Whitman's place in the American scene and investigate through various media the issues that he raised in his poetry and prose. Edited by Tyler Hoffman, an assistant professor of American literature and cultural studies, along with J.T. Barbarese, an assistant professor of creative writing and American literature, $M S R$ features some of the best and most exciting work currently being done in the fields of Whitman Studies and American Studies, with a focus on the region in which Whitman lived and worked, from New York City to Washington, D.C., centering on his home in Camden. The journal's mix of poetry, fiction, essays, archival documents, reviews, and visual art seeks to facilitate interdisciplinary exchanges among creative writers, artists, teachers, and scholars interested in American literature and culture in Whitman's day and beyond.

The Mickle Street Review was begun in 1979 by Geoffrey Sill and Frank McQuilkin as a joint project of the Walt Whitman House, a State of New Jersey historic site, and Rutgers University in Camden. The journal ceased publication in 1991 for financial reasons. In its new electronic incarnation, The Mickle Street Review (http://www.micklestreet.rutgers.edu) supports both the American Studies and the creative writing programs at the graduate and undergraduate schools of Rutgers-Camden and continues in its alliance with the 